Faculdade

de Ciências Econômicas UFRGS

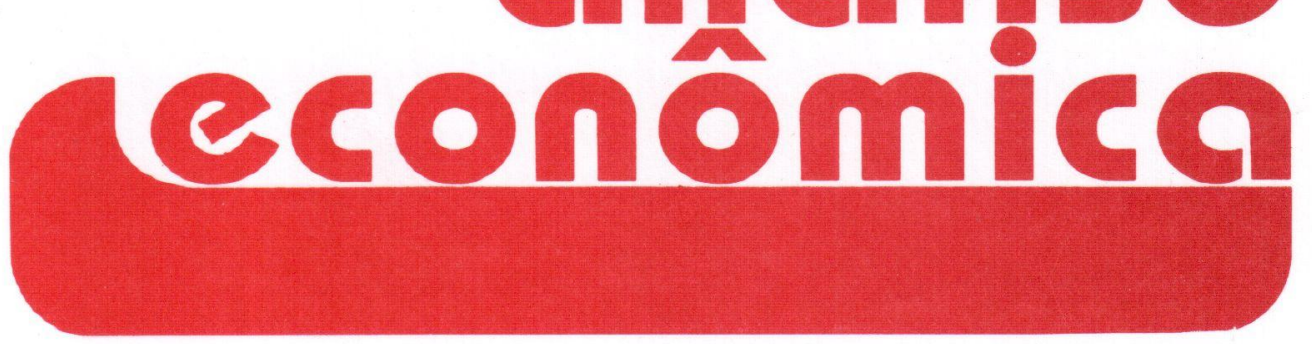

Balança Comercial e Capacidade

Produtiva da Indústria de Transformação

- Flávio Benevett Fligenspan

- Jeferson Luis Bittencourt

Breves Reflexões sobre a Relevância

da História da Teoria Econômica

- Gilberto Tadeu Lima

A Competitividade do Arroz Gaúcho

e seus Condicionantes

- Augusto M. Alvim

- Carlos G. A. Mielitz Netto

Uma Análise da Economia de Ricardo

- Liderau S. Marques Junior

A Estratégia de Substituição de

Importações Revisitada

- Alex Pereira Benício

- Joanílio Rodolpho Teixeira

The Refinements of the Orthodox Macroeconomic Theory and the Post Keynesian Theory

- Fernando Ferrari Filho

Instrumentos de Gestão Ambiental

- Jaildo Santos Pereira

- Vitor Emanuel Tavares

The Economic Implications for

Sustainable Mining

- Dina Franceschi

- James R. Kahn

Mudança Institucional e Estrutural na

Economia Brasileira do Início dos Anos Noventa

- Eduardo Simões de Almeida
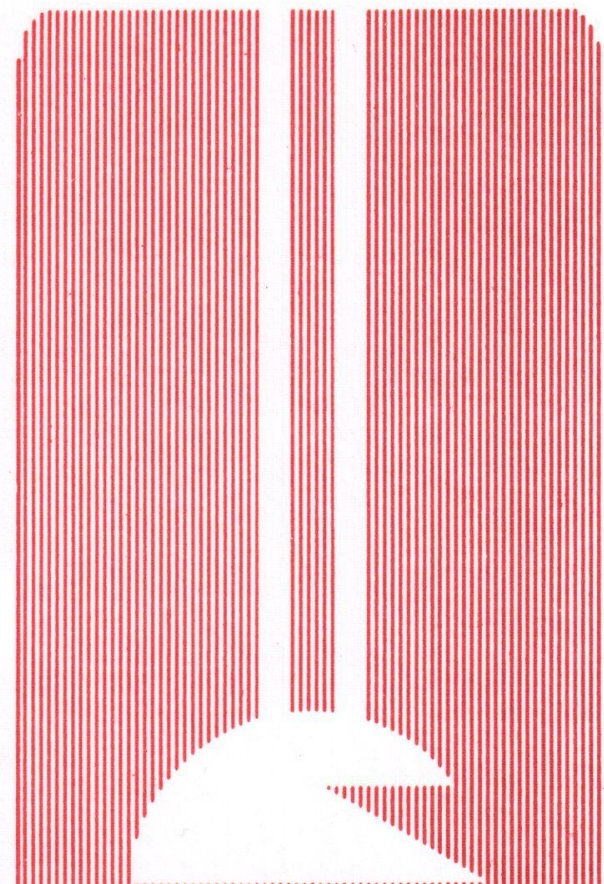

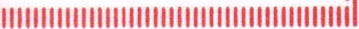
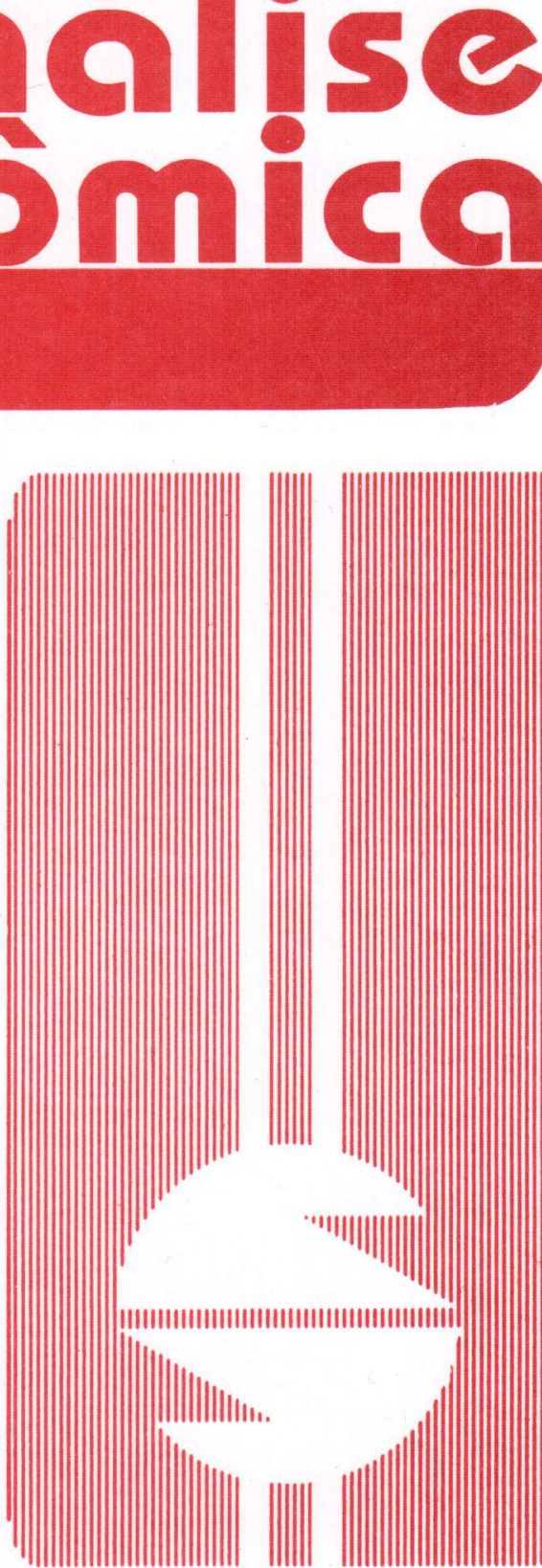
UNIVERSIDADE FEDERAL DO RIO GRANDE DO SUL

Reitora: Prof ${ }^{a}$. Wrana Maria Panizzi

FACULDADE DE CIÊNCIAS ECONÔMICAS

Diretora: Prof . Otilia Beatriz Kroeff Carrion

CENTRO DE ESTUDOS E PESQUISAS ECONÔMICAS

Diretor. Prof. Fernando Ferrari Filho

DEPARTAMENTO DE CIÊNCIAS ECONÔMICAS

Chefe: Prof. Luiz Alberto Oliveira Ribeiro de Miranda

CURSO DE PÓS-GRADUAÇÃO EM ECONOMIA

Coordenador. Prof. Marcelo Savino Portugal

CURSO DE PÓS-GRADUAÇÃO EM ECONOMIA RURAL

Coordenador. Prof. Carlos Guilherme A. Mielitz Netto

CONSELHO EDITORIAL: Achyles B. Costa, Aray M. Feldens, Carlos A. Crusius, Carlos G. A. Mielitz Netto, Eduardo A. Maldonado Filho, Eduardo P. Ribeiro, Eugênio Lagemann, Fernando Ferrari Filho, Gentil Corazza, Marcelo S. Portugal, Nali J. Souza, Otília B. K. Carrion, Paulo A. Spohr, Paulo D. Waquil, Pedro C. D. Fonseca, Roberto C. Moraes, Ronald Otto Hillbrecht, Stefano Florissi, Eleutério F. S. Prado (USP), Fernando H. Barbosa (FGV/RJ), Gustavo Franco (PUC/RJ), João R. Sanson (UFSC), Joaquim P. Andrade (UnB), Juan H. Moldau (USP), Paul Davidson (Univ. of Tennessee), Werner Baer (Univ. of lllinois).

COMISSÃO EDITORIAL: Eduardo Augusto Maldonado Filho, Fernando Ferrari Filho, Gentil Corazza, Marcelo Savino Portugal, Paulo Dabdab Waquil; Roberto Camps Moraes.

EDITOR: Gentil Corazza

EDITOR ADJUNTO: Pedro Silveira Bandeira

SECRETARIA: Fábio Sparremberger. Revisão de textos: Vanete Ricacheski.

FUNDADOR: Prof. Antônio Carlos Santos Rosa

Os materiais publicados na revista Análise Econômica são da exclusiva responsabilidade dos autores. É permitida a reprodução total ou parcial dos trabalhos, desde que seja citada a fonte. Aceita-se permuta com revistas congêneres. Aceitam-se, também, livros para divulgação, elaboração de resenhas e recensões. Toda correspondência, material para publicação (vide normas na terceira capa), assinaturas e permutas devem ser dirigidos ao seguinte destinatário:

PROF. GENTIL CORAZZA

Revista Análise Econômica - Av. João Pessoa, 52 CEP 90040-000 PORTO ALEGRE - RS, BRASIL 


\title{
MUDANÇA INSTITUCIONAL E ESTRUTURAL NA ECONOMIA BRASILEIRA DO INÍCIO DOS ANOS NOVENTA
}

\author{
Eduardo Simões de Almeida ${ }^{(*)}$
}

\begin{abstract}
RESUMO
Este artigo tem por objetivo tentar explicar as grandes transformações que impactam a economia brasileira desde o início dos anos noventa. Analisamos a evolução histórica dos condicionantes de seu ambiente econômico, marcada pela adoção do Modelo de Substituição de Importações. Neste contexto, consideramos que a implementação da abertura econômica, promovida pela Política Industrial e de Comércio Exterior (Pice), representou uma grande mudança institucional que alterou profundamente $o$ ambiente econômico brasileiro, dando origem à mudança estrutural e tecnológica. A abertura econômica induziu a mudança de comportamento tecnológico das empresas. Por último, procuramos testar algumas hipóteses desenvolvidas ao longo do artigo, fazendo uso de série de produtividade do trabalho. Realizamos análise de outliers, aplicando um novo método chamado Joint Estimation Procedure, desenvolvido por Chen \& Liu no início dos anos noventa.
\end{abstract}

Cód. AEA: 121

Palavras-chave: mudança institucional, abertura econômica e análise de outliers.

\begin{abstract}
This article is aimed at trying to explain the great transformations which have impacted the brazilian economy since the beginning of the nineties. We analyze the historical evolution of the conditions of its economic environment, pointed out by the adoption of the Import Substitution Model. In this context, we consider that the accomplishment of the economic openness, promoted by the Foreign Trade and Industrial Policy (Pice), stood for a great institutional change that modified deeply the brazilian economic environment, originating the structural and technological change. The economic openness have induced the change of technological behavior of the firms. At last, we intend to test some assumptions developed through the article, using labor productivity serie. We achieve outlier analysis, applying a new method called Joint Estimation Procedure, developed by Chen \& Liu in the beginning of the nineties.
\end{abstract}

AEA Code: 121

Key words: institutional change, economic openness and outlier analysis

(") Doutorando em Economia pela FEA-USP e pesquisador científico da FIPE.

\begin{tabular}{|l|l|l|l|l|}
\hline ANÁLISE ECONÔMICA & ANO 17 & N. 31 & Março/99 & p. 157-189 \\
\hline
\end{tabular}




\section{1 - INTRODUÇÃO}

O fenômeno da abertura econômica constituiu-se no grande evento impactante na economia brasileira do começo dos noventa, engendrando uma grande mudança institucional que posteriormente provocou mudanças de cunho estrutural, ao modificar a conduta e as estratégias das empresas que atuam no ambiente econômico brasileiro.

A formação histórica do ambiente econômico brasileiro foi marcada pela vigência do Modelo de Substituição de Importações (MSI). A década de oitenta presenciou a crise deste modelo. No que diz respeito às raízes desta crise, a interpretação convencional procura associá-la a duas outras crises: a financeira e a fiscal. Neste artigo, procurar-se-á dar uma interpretação de conteúdo mais estrutural e tecnológico ao esgotamento do MSI.1

A abertura econômica, na forma do anúncio e da implementação da Política Industrial e de Comércio Exterior (Pice), será entendida como uma resposta à crise estrutural do $\mathrm{MSI}$, modificando drasticamente as regras do jogo econômico no qual estão inseridas as empresas brasileiras e conduzindo a um choque de produtividade no ambiente.

Na literatura recente de economia brasileira, a existência do choque da produtividade dos anos noventa é abordada tanto teoricamente quanto no plano empírico. No plano teórico, as mais freqüentes justificativas que sustentam a existência do choque de produtividade são referentes a um processo de reorganização dos mercados, acarretando eficiência técnica e incorporação de progresso técnico (Franco, 1996a, 1996b; Moreira \& Correa, 1997).

A interpretação deste artigo destaca, sem deixar de levar em conta estes aspectos, as características institucionais que colaboram para moldar o comportamento empresarial no ambiente econômico, em especial a superação das diversas fontes de ineficiência e atenuamento do comportamento rentista pós-abertura.

No plano empírico deste debate, existem alguns estudos que contestam a ocorrência de um choque de produtividade, concentrando suas críticas em questões metodológicas a respeito da qualidade estatistica da medida de produtividade (Considera \& Silva, 1993; e Pastore \& Pinotti, 1994). Um outro grupo de estudiosos, no momento majoritário, registra a ocoirência do choque de produtividade e apresenta fartas evidências empíricas em favor desta hipótese (Bielschowsky \& Stumpo, 1996; Bonelli, 1996, Amadeo, 1996, Feijó \& Carvalho, 1994).

Neste artigo, algumas evidências empíricas são apresentadas a fim de testar a hipótese de existência de choque de produtividade. Os dados usa-

\footnotetext{
${ }^{1}$ Ver também a este respeito Franco (1996a).
} 
dos para o teste de hipóteses são a série univariada de produtividade média industrial de trabalho, calculada pela PIM-IBGE. Uma vez que se trata de série de tempo interrompida (isto é, que sofreram intervenções ou políticas de tratamentos), aplicou-se - para implementar o teste de hipóteses - um novo método de estimação e detecção de outliers, denominado Joint Estimation Procedure, desenvolvido na literatura estatística por Chen \& Liu (1993a; 1993b; e 1991).

Este artigo está estruturado em cinco seções, contando com esta de caráter introdutório. A próxima seção trata da evolução histórica dos condicionantes do ambiente econômico e de seus problemas de longo prazo. A terceira seção apresenta a natureza e a lógica da mudança institucional radical por que passou o pais no começo dos anos noventa, alterando sua trajetória evolutiva. A quarta seção é reservada a realização do teste de hipóteses baseado na análise de outliers para os dados de produtividade do trabalho. Por fim, nas conclusões, procura-se recuperar os resultados tanto teóricos quanto empíricos - obtidos ao longo do artigo.

\section{2 - CARACTERIZAÇÃO DO AMBIENTE ECONÔMICO BRASILEIRO DESDE 1930}

Ambiente econômico é a atmosfera em que as empresas operam e pela qual são influenciadas em seu comportamento e desempenho. É o conjunto de condicionantes que tem o poder de influenciar a tomada de decisão estratégica da empresa. Os seus principais condicionantes são: a) configuração estrutural dos mercados; b) padrão de competição; c) arcabouço jurídico-regulatório; d) estrutura de impostos, subsidios e encargos (sociais e trabalhistas); e) condições macroeconômicas; f) nível de sindicalização e estágio das relações capital - trabalho.

A idéia básica é de que o ambiente econômico engendra estímulos, oportunidades, desafios, enfim, sinais que são captados pelo universo das empresas e induzem respostas particulares destas em termos de conduta e desempenho. Tais respostas exercem, por sua vez, influência nos condicionantes que determinam as características do ambiente econômico. As empresas, neste enfoque, são essencialmente reativas ao ambiente econômico. Sua reação, entretanto, depende de dois fatores: a) a natureza e a intensidade dos sinais transmitidos pelo ambiente; b) a capacidade intrínseca de cada firma em captar, interpretar e reagir a estes sinais. $O$ ambiente econômico executa, portanto, a função de mecanismo de indução de mudanças no comportamento das empresas - em especial, no que diz respeito à realização de seus esforços de busca (atividades inovativas, imitativas e de aprendizado). 
A gestação do ambiente econômico brasileiro nos últimos sessenta anos foi marcada pela adoção do país da chamada estratégia de industrialização baseada na substituição de importações. Esta estratégia teve início com estrangulamento externo causado pela crise de 29 , e assumiu a forma de uma grande redução da capacidade de importar, em virtude da abrupta deterioração do poder de compra das exportações e da própria diminuição do quantum exportado, provocando déficits na balança comercial e no balanço de pagamentos. Tal fenômeno gerou a necessidade de se adotar medidas restritivas das importações mediante manipulação da política cambial no sentido de desvalorizar a moeda2 ou mesmo a sua proibição direta, que acarretou elevados preços relativos dos bens importados, gerando oportunidades econômicas a serem exploradas pelos produtores domésticos (Suzigan, 1986; Candal, 1977, p.242-3; Baer, 1966, p.21-2).

$A$ industrialização brasileira foi baseada neste modelo, que exigia, dentro de sua lógica, a criação de um ambiente econômico protegido para a produção industrial doméstica. Com este objetivo foram introduzidos instrumentos de proteção - tanto tarifários (e não-tarifários) quanto cambiais -, assim como envolveu a concessão de subsídios fiscais, creditícios e financeiros a qualquer pessoa que se dispusesse a produzir no Brasil. (Suzigan, 1996; 1986 e 1975; Huddle, 1972).

Este Modelo de Substituição de Importações (MSI) adotado pelo Brasil foi bem-sucedido em forjar um ambiente econômico que induzisse as empresas a se preocuparem constantemente com a busca de inovações e a absorção de progresso tecnológico? Em outros termos, foi o modelo de desenvolvimento orientado para dentro - seguido pelo país - capaz de promover competitividade e dinamismo tecnológico? ${ }^{3}$

\footnotetext{
${ }^{2} \mathrm{~A}$ desvalorização da moeda, ao lado da expansão do crédito aos cafeicultores, foi o mecanismo de proteção de renda do setor exportador encontrado pelo governo brasileiro para enfrentar a crise de 29. A manutenção de renda representou um estímulo adicional ao processo de industrialização brasileiro empreendido naquela época, pois garantia o nivel da demanda agregada no mercado para a produção de bens produzidos internamente (Furtado, 1987).

${ }^{3}$ Esta é uma questão fundamental que está sendo abordada por vários autores nos últimos anos. Segundo Franco (1996b, p. 10), "Por um longo tempo o Brasil tem seguido o que foi apropriadamente definido como um modelo de crescimento orientado para dentro, intensivo em regulamentação governamental, cujas ineficiências associadas, custos fiscais e imperfeições competitivas impingidas sobre a estrutura industrial, entre outros defeitos, estavam contribuindo para geração de alta inflação no Brasil". Conforme Fleury (1995, p. 78), "Na escala de competitividade apresentada anteriormente, as empresas brasileiras não estavam preocupadas com competição no estrito senso do termo. A maioria destas companhias não conduziam adequada avaliação de custos e, quando a preocupação com qualidade existia, ela era de importância secundária". De acordo com Barros \& Goldenstein (1996, p. 12), "O fechamento da economia eliminava a concorrência,
} 
Competitividade é a capacidade demonstrada pelas empresas de revelar bom desempenho - em termos de conquista de market share, obtenção de rentabilidade - no mercado na medida em que elas conseguem "pelo menos, igualar os padrões de eficiência vigentes no resto do mundo quanto à utilização de recursos e à qualidade do bem" (Araújo Jr., 1996, p.81). Evidentemente, competitividade não é apenas um atributo da empresa, mas também guarda relação com os condicionantes e características de um ambiente econômico (o arcabouço institucional, as politicas públicas etc), que as estimulam a adotar determinada conduta.

Normalmente, a primeira fonte de competitividade - os chamados fatores espúrios - é centrada na variável preço, atendido um certo nivel de qualidade. Os fatores de competitividade autênticos são centrados no impacto sobre o estado qualitativo do produto e/ou sobre os seus custos (preços). ${ }^{4}$.

Entretanto a competitividade obtida através da variável preço pode ser alcançada mediante o acúmulo de fatores espúrios. É possível extrair vantagens competitivas de fatores como a abundância de recursos naturais, salários baixos, câmbio desvalorizado, concessão de subsídios para empresas por parte do governo etc, que permitem às empresas desfrutar durante um certo periodo de competitividade - baseada em preço - no mercado. Historicamente, contudo, está provado que indústrias ou países que se apoiaram nestes fatores não conseguiram sustentar sua posição competitiva durante muito tempo. Eles estão sendo superados por empresas, indústrias ou países que fundamentavam sua competitividade na absorção permanente de progresso tecnológico.

O progresso tecnológico tende a fazer com que estes fatores percam sua importância na determinação da competitividade de um país no longo prazo. ${ }^{5}$ Atividade de inovação ${ }^{6}$ contínua é o fator fundamental para a ma-

desobrigando as indústrias de novos investimentos e fortalecendo o processo inflacionário uma vez que quaisquer custos podiam ser automaticamente repassados para preços". ${ }^{4}$ Os conceitos de competitividade espúria e autêntica foram apresentados por Fajnzylber (1988). Este autor, no entanto, considerava o progresso tecnológico - o grande determinante do fator autêntico de competitividade - em um sentido mais estrito. Para Fajnzylber, progresso tecnológico apenas se manifestava em aumento de produtividade dos insumos. Diferentemente deste autor, considera-se aqui, além deste efeito, também o impacto sobre a melhoria de qualidade do produto e sua manutenção ao longo do tempo.

${ }^{5}$ No que tange aos recursos naturais, alguns exemplos são ilustrativos desta proposição. Com o avanço tecnológico, a borracha natural foi substituida pela borracha sintética; 0 ferro e o aço estão disputando mercado, em condições cada vez mais desfavoráveis, com o plástico e os novos materiais; a biotecnologia, na agricultura, compensa vantagens (ou desvantagens) como condições climáticas e propriedades naturais de solo.

${ }^{6}$ Neste artigo, trabalha-se com o conceito de inovação em suas duas acepções: a schumpeteriana ('estrita'); e a nelsoniana ('ampla'). A inovação na acepção schumpeteriana exige que ela se constitua uma novidade no sistema econômico. Assim sendo, existe o requisito do ineditismo da novidade introduzida no sistema: se, por acaso, a inovação se 
nutenção e obtenção de competitividade em ambientes econômicos dinâmicos. Assim, o sucesso ou fracasso de uma estratégia de desenvolvimento está condicionado ao fato de se criar o ambiente econômico e as bases para conduzir as empresas do país a serem competitivas em nivel internacional.

À luz destas considerações serão apresentados e analisados os principais problemas detectados na estratégia de desenvolvimento seguida pelo país e que foram responsáveis pela caracterização de seu ambiente econômico.

\section{1 - A ausência de seletividade estratégica do MSI}

A lógica do $\mathrm{MSI}$ prescrevia uma industrialização autônoma para dentro, no sentido de ser integrada e pouco dependente de importações. Integrada no sentido de ter uma estrutura produtiva verticalizada e interdependente, em que se endogenizasse o setor dinâmico do sistema, isto é, o setor de bens de capital, identificado como o gerador de progresso técnico para o restante dos setores. Conseqüentemente, tal estrutura produtiva dependeria, depois que a industrialização se encontrasse em um estágio avançado, de poucas importações e reproduzir-se-ia automamente mediante a endogenização no sistema do motor do crescimento - o setor de bens de capital.

Para se atingir o objetivo da constituição de uma estrutura produtiva integrada, verticalizada e independente, houve a necessidade de não se adotar a seletividade estratégica no conjunto de políticas econômicas que embasaram a implementação da política de desenvolvimento. A ausência de seletividade estratégica implicou que todos os setores fossem protegidos sob o argumento da indústria nascente (ou infante). O governo brasileiro estendeu uma ampla rede de proteção, subsídios - diretos e indiretos (manipulação de preços públicos de eletricidade, energia, aço, telecomunicações etc) - e incentivos a qualquer produtor que desejasse suprir o mercado interno com bens produzidos domesticamente. Válido, portanto, para todos

corporificar em produto, este produto lançado por uma firma deve ser o primeiro até então já lançado no sistema e assim por diante. Todas as outras firmas que seguirem o líder e lançarem esta novidade no sistema econômico estarão simplesmente participando do processo de difusão inovativa, conforme denominou Schumpeter (1934 e 1939). Por sua vez, a inovação na acepção nelsoniana (ou 'ampla') prescinde do ineditismo exigido na acepção anterior. Segundo Nelson (1993, p 4): "Considere o termo inovação. Neste estudo, interpretamos o termo amplamente, para incorporar os processos que as firmas aprendem a dominar e põem em prática designs de produtos e processos manufatureiros que são novos a elas [as firmas], se não para o universo [de firmas] ou mesmo para o país". Deste modo, inovação, para este autor, é uma novidade bem assimilada e aplicada por uma empresa, e que ajuda tal empresa a ter bom desempenho no mercado, mesmo que já tenha sido introduzida por uma outra empresa anteriormente. 
os setores, independente de uma análise mais pormenorizada das reais vantagens comparativas potenciais de que gozavam tais setores. ${ }^{7}$

\section{2 - MSI como um fim em si mesmo e a falta de cobrança}

A concessão de subsídios fiscais, creditícios e financeiros, além do mercado protegido, ao setor privado por parte do governo foi feita sem que este último deixasse explícito o compromisso de estabelecer critérios exante ou ex-post de exigência de desempenho como, por exemplo, o alcance de metas de exportações e incorporação de progresso técnico. Os incentivos ficaram desvinculados de qualquer espécie de cobrança. Era como se a industrialização fosse um objetivo em si mesmo e não um meio para se atingir conquistas sócio-econômicas de longo prazo (Barros \& Goldenstein, 1997).

Ao promover o MSI, o governo não fixou um prazo para expor a estrutura produtiva à competição internacional, ou seja, submeter a produção doméstica ao teste do mercado externo. As autoridades econômicas e os empresários comportaram-se como se o MSI não tivesse prazo para terminar. A ausência de um horizonte temporal definido de vigência do $\mathrm{MSI}$, ao longo do qual o grau de proteção e o nível de subsidios seriam progressivamente cadentes, constituiu-se em elemento de deturpação do princípio da indústria nascente. Este é um argumento adicional para a hipótese de que o MSI não teve um caráter estratégico. A falta de cobrança está ligada à inexistência de objetivos de longo prazo por parte do governo (Suzigan, 1996).

\section{3 - Eliminação da competição}

O padrão de competição de um ambiente econômico diz respeito ao grau de concorrência efetiva e potencial (contestabilidade) ${ }^{8}$ prevalecentes nos mercados e em que medida influencia o comportamento das empresas e seu desempenho.

Há quatro fontes de competição - quer efetiva quer potencial - em um mercado: a) concorrência efetiva vinda do mercado interno pelas empresas dentro da indústria; b) concorrência efetiva proporcionada por importações que abastecem o mercado; c) concorrência potencial (contestabilidade) proporcionada pela ameaça de se importar; d) concorrência potencial (con-

\footnotetext{
${ }^{7}$ Eventualmente, politicas industriais mais verticais favoreciam algumas indústrias, que, em determinado momento, eram consideradas importantes, com mais proteção e/ou concessão de maiores subsídios (cambiais, crediticios etc). Contudo, tais iniciativas esporádicas não tinham continuidade no tempo, denotando uma outra característica - a nãoseqüencialidade dos planos e das políticas (Suzigan, 1996, p. 15). Não houve uma seleção das indüstrias que possuiam vantagens comparativas potenciais para serem nomeadas como estratégicas (como ocorreu na Coréia do Sul).

${ }^{8}$ Para uma definição do conceito de contestabilidade, ver Willig (1987).
} 
testabilidade) proporcionada pela ameaça de entrada de novas empresas (estrangeiras ou nacionais de outros setores) no mercado.

A primeira fonte de competição (item a) tem relação com a rivalidade interfirma doméstica no mercado. A rivalidade interfirma, por sua vez, depende, em certo grau, do número de empresas presentes no mercado (grau de concentração), barreiras à entrada e à saída etc. As fontes de competição $c$ e $d$ referem-se à contestabilidade dos mercados.

A segunda fonte - a entrada efetiva de importações no mercado - guarda vínculo com a rivalidade interfirma no âmbito internacional. Pode assumir diversas dimensões: empresa nacional $X$ empresa estrangeira, ${ }^{9}$ empresa transnacional (ETN) $X$ empresa estrangeira ou empresa estrangeira $X$ empresa estrangeira. A rivalidade na dimensão empresa nacional contra empresa estrangeira representa uma luta pelo mercado doméstico em que a firma sediada no país usa como arma a sua produção, enquanto que a firma estrangeira procura penetrar com importações. ${ }^{10} \mathrm{~A}$ empresa estrangeira pode usar a estratégia de perscrutar, inicialmente, as características do mercado através de importações para, em um segundo momento, depois de verificadas as potencialidades do mercado e fixada uma imagem junto do consumidor, resolver entrar no mercado em condições mais favoráveis. É interessante notar que, neste caso, as importações constituem-se em um prenúncio do ingresso no mercado pela empresa estrangeira, que se transformará para este país, na fase pós-ingresso, em ETN. Neste sentido, toda importação efetiva traz no seu bojo a ameaça de entrada futura da empresa estrangeira exportadora e, portanto, o germe da competição potencial (contestabilidade).

No Brasil, todas estas fontes foram suprimidas ou atenuadas ao extremo, determinando um baixo padrão de competição nos mercados e ambiente econômico.

O fenômeno da eliminação da competição do ambiente econômico brasileiro marcou indelevelmente a trajetória de crescimento e a capacidade de

\footnotetext{
${ }^{9}$ Empresa estrangeira, ao contrário da ETN, é a firma que não tem filial (unidade produtiva) no país, mas que pode participar do mercado interno do país através de exportações.

${ }^{10}$ Cabe frisar a relevância das importações como um compromisso para uma futura e posterior entrada no mercado doméstico. Diversas empresas estrangeiras utilizam as importações como uma espécie de teste de mercado. Ou seja, procuram avaliar os gostos dos consumidores domésticos, reforçar o seu nome ou marca na consciência e confiança dos consumidores, ganhar escala mínima como ponto de partida para a futura produção, além de conquistar market share. As importações são importantes para as empresas estrangeiras, a fim de não terem de começar da estaca zero. (Barros \& Goldenstein, 1997, p.13).
} 
competitividade do país. É possivel dividir este fenômeno em dois aspectos: o estrutural e o institucional. ${ }^{11}$

Do lado estrutural, a adoção do MSI a partir de 1930, em virtude de sua própria lógica, implicou a șupressão de todas as fontes de competição da economia brasileira. A reserva de mercado para os produtores domésticos foi proporcionada pela proteção cambial até aproximadamente 1957 através das diversas políticas de câmbio promovidas pelo governo - controles cambiais expressos em licenciamento de importações (1947-53) e sistema de taxas múltiplas de câmbio (1953-1957). A partir do final dos anos 50, houve uma tendência em direção à liberalização do câmbio (Baer, 1966; Suzigan, 1975; Huddle, 1973).

Em 1957, com a aprovação da Lei 3.244 (chamada também de lei das tarifas) que estabeleceu alíquotas ad valorem entre 0 e $150 \%$, a proteção começou a assumir uma natureza mais tarifária, ao lado de um reforço das barreiras não-tarifárias e ainda de controles cambiais, que perdurou até os estertores do $\mathrm{MSI}^{12}$ Até aquela data, as tarifas de importação no Brasil eram de natureza específica, cujo valor estava fixo há muito tempo e foi corroído, em termos reais, pelo efeito da inflação acumulada (Suzigan, 1996, p.10; Baer, 1966, p.56). O alto grau de proteção foi expressa tanto na manipulação de tarifas quanto em barreiras não-tarifárias, assumindo a forma de legislação ou regulamento burocrático (Lei dos Similares, índice de nacionalização e o anexo C da Cacex) (Suzigan, 1996; Suzigan, 1975; Baer, 1966, p.56-58; Candal, 1977, p.271).

A aplicação mais rigorosa da Lei do Similar Nacional, que existia desde o século passado, constituiu-se em mecanismo de reserva de mercado para os produtores nacionais. ${ }^{13}$ Esta lei ordenava que qualquer importação de um certo produto ficasse proibida, caso algum produtor doméstico se dispuses. se a fabricar um bem similar ao importado. A conseqüência desta medida

\footnotetext{
${ }^{11}$ Cabe ressaltar que, evidentemente, não se está considerando que estes aspectos sejam completamente estanques, sem relacionamento entre si. Pelo contrário, logo se perceberá, por meio da exposição abaixo, que existe um forte imbricamento entre os aspectos, no sentido de que o aspecto estrutural é em larga medida determinante do aspecto institucional da eliminação da competição.

12 "A principal novidade foi a Lei de Tarifas, de 1957, cujo propósito era proteger adequadamente as novas indústrias que vinham sendo estimuladas". (...). "A Lei de Tarifas Aduaneiras de 1957 ampliou e consolidou a proteção à indústria interna em crescimento. Em muitos caso as tarifas se elevaram a 60, 80 e 150 por cento" (Baer, 1966, p.57-58).

13 "A Lei de Similares é atualmente utilizada para dar cobertura a todo tipo de expedientes de proteção aos bens produzidos no país e que tenham natureza similar aos importados. A definição exata da expressão "qualidade e quantidade adequadas", exigidas para que um produto pudesse obter proteção, foi deixada em termos bastante flexiveis na lei e as autoridades administrativas a utilizaram com larga margem de arbítrio". (Baer, 1966, p.61).
} 
foi banir do mercado brasileiro produtos vindos do exterior e anular duas importantes fontes de competição: a concorrência efetiva e potencial (contestabilidade) proporcionada pelas importações.

A primeira fonte de competição foi demasiadamente atenuada pela forma como se deu a importação de tecnologia. Dado o tamanho reduzido do mercado interno ${ }^{14}$ e o fato de que a industrialização ter sido feita basicamente com a importação de tecnologia - que assumiu a forma de incorporação de máquinas e equipamentos por parte das empresas e ter exigido grandes escalas de produção - determinou-se a estrutura oligopolística de mercado de diversos setores industriais, condicionando a existência de poucas empresas com capacidade de serem eficientes economicamente. A idéia básica é de que os bens de capital importados (e, por extensão, as plantas industriais) de países desenvolvidos, refletindo a sua dotação de fatores, isto é, intensivos em capital, exigem uma escala de produção mínima para se atingir determinados padrões de eficiência (Merhav, 1987). A concorrência vinda do mercado interno pelas empresas dentro da indústria ficou enfraquecida por motivos estruturais.

O fato do ambiente econômico brasileiro apresentar uma predominância de estruturas oligopolísticas de mercado favoreceu o estabélecimento de arranjos cartelizados entre as empresas, diminuindo a rivalidade competitiva efetiva entre as empresas. Além disso, como a dimensão do mercado brasileiro comportava um determinado número de empresas eficientes, ${ }^{15}$ a concorrência potencial advinda da ameaça da entrada de novas firmas no mercado era reduzida, pois debilitava o ânimo das potenciais empresas ingressantes, quando estas sabiam que a sua entrada detonaria uma luta pela sobrevivência, em que algumas firmas teriam que se retirar do mercado. Nestas condições, o nível de incerteza do sucesso de uma investida em um mercado por parte de uma ingressante alcançava níveis elevados, inibindo a iniciativa da entrada. A partir deste ponto, e grosso modo, a própria expansão do mercado consumidor era explorada pelo crescimento da oferta das empresas já instaladas, aproveitando-se de suas vantagens iniciais.

Do lado institucional, ao longo do processo de desenvolvimento brasileiro houve a criação de uma série de barreiras institucionais à entrada de novos agentes nos mercados, restringindo a contestabilidade nos mercados. Neste aspecto, a influência do Conselho de Desenvolvimento Industrial (CDI) foi decisiva, uma vez que era o órgão responsável pela administração

\footnotetext{
${ }^{14}$ Apesar da população brasileira ser grande desde a década de 40 ou 50 e se expandir a taxa crescente, a perversa distribuição de renda deixava amplos segmentos sociais alijados do mercado consumidor.

${ }^{15}$ A despeito deste mercado consumidor estar se expandindo a taxas crescentes, em decorrência do forte crescimento econômico e populacional experimentado pelo pais no período.
} 
da concessão de incentivos fiscais para a aquisição de bens de capital importados destinados à execução de projetos industriais - tanto de empresas que já atuavam no país quanto de empresas estrangeiras interessadas em ingressar no mercado brasileiro. O poder de tal órgão praticamente determinava a apreciação e aprovação dos projetos de instalação de plantas industriais por parte de ETNs ou a ampliação de capacidade produtiva de empresas já atuantes no país. Na prática, este órgão administrava a entrada de empresas e produtos no mercado, atuando como uma barreira institucional à entrada e impondo limites a uma maior competição e contestabilidade no ambiente econômico (Suzigan, 1978, p.63-4).

\section{4 - A demanda insatisfeita e a solução tecnológica fácil}

A resposta da oferta de bens domésticos aos estímulos de política econômica que fundamentaram o MSI deu-se em circunstâncias especiais do lado da demanda. Antes do produtor doméstico atender ao mercado, este mercado já estava sendo suprido pelas importações, e os consumidores conheciam as especificações do produto, e portanto estavam acostumados ao produto importado. Com a Lei dos Similares, o produtor doméstico ganhava o privilégio do mercado protegido para a sua produção, sem a concorrência dos bens importados. Ademais, havia grande potencialidade do mercado interno devido às características da demanda insatisfeita, que se efetivou com a dinâmica do crescimento econômico que o país experimentou. O crescimento da economia incorporava novas legiões de consumidores aos mercados de bens dinâmicos (com alta elasticidade-renda da demanda), que anteriormente estavam confinados ao nível de subsistência.

Isto conduziu a uma situação curiosa em que havia a existência de mercados tomados pela demanda insatisfeita dos consumidores, grandes oportunidades econômicas (mudança de preços relativos a favor da produção doméstica proporcionada pela proteção tarifária e cambial) e fortes incentivos para investir dos produtores domésticos - representados pelos ganhos monopólicos para os primeiros a entrarem no mercado, atendendo a um patamar mínimo de qualidade exigido pelos consumidores conhecedores do produto a ser substituido (Biato, 1973).

Se o produtor doméstico resolvesse suprir um mercado até então abastecido por importações, sairia na frente da concorrência e desfrutaria dos ganhos monopólicos. Tais ganhos de monopólio já estavam postos de antemão, cabia apenas ver quem seria o beneficiário. $E$ o beneficiário não era o inovador, mas o indivíduo que conseguia responder mais prontamente à demanda insuficiente. É interessante perceber que os ganhos de monopólio recebidos pelo produtor não tinham relação com o grau de inovatividade do produto colocado no mercado, podendo este ser até inferior qualitati- 
vamente ao bem importado substituído, desde que atendesse a um patamar mínimo de qualidade. ${ }^{16}$

Tal confluência de condições determinou a adoção da solução tecnológica fácil, ou seja, a importação de tecnologia - tanto na forma de acordos de transferência de tecnologia quanto na forma de investimento direto pelas empresas transnacionais (ETN) -, em virtude da concorrência intercapitalista entre os produtores. A conclusão é de que a existência de mercados tomados pela demanda insuficiente determinou o estado de arte tecnológico de diversos setores. Este processo de importação de tecnologia representava um salto do estado de arte tecnológico, auxiliando o país, num primeiro momento, a se aproximar estaticamente da fronteira mundial tecnológica.

\section{5 - O viés da dinâmica tecnológica}

O problema advindo da importação de tecnologia surge quando se analisa a dinâmica tecnológica, ou seja, como ocorre o desenvolvimento daquele estado de arte tecnológico ao longo do tempo. Este desenvolvimento depende dos estímulos a que estão submetidas as empresas no ambiente econômico. Se o ambiente econômico lançar desafios, apresentar oportunidades e conseguir forjar um clima inovativo, as firmas engajar-se-ão em atividades tecnológicas. Porém o ambiente econômico é condicionado pelo padrão de competição vigente nos mercados. Conseqüentemente, a dinâmica tecnológica depende, em larga medida, do padrão de competição.

A dinâmica tecnológica é entendida como o processo que leva à eficiência produtiva (redução de custos) e constante melhoria de qualidade do produto. No Brasil, a dinâmica tecnológica apresentou limitações na esfera da obtenção de economias de escala. O mercado consumidor brasileiro efetivo, relativamente pequeno em comparação com o de países desenvolvidos, conduziu ao estabelecimento de tamanhos pequenos da planta industrial que, por sua vez, cerceava as fontes de crescimento da eficiência microeconômica (possibilidade para a substituição capital/trabalho e economias de escala).

Outro fator limitador foi o alto grau de verticalização observado na economia brasileira pelas empresas, expresso pela reduzida especialização e pequeno uso da subcontração. Isto deveu-se ao fato de que os fornecedores domésticos serem incapazes de ofertar seu produto a um preço baixo e segundo especificações técnicas que resguardassem o principio da qualidade, do cumprimento de prazos e prestação de assistência técnica. As razões desta incapacidade por parte dos fornecedores residiam em duas ordens - uma afetando custo e, em conseqüência, preço; e a outra referin-

\footnotetext{
${ }^{16}$ Este padrão de qualidade mínimo foi introduzido nas escalas de preferências dos consumidores brasileiros pelas importações pretéritas de bens do exterior.
} 
do-se a considerações de qualidade. A primeira razão diz respeito também ao pequeno tamanho do seu mercado, que os impedia de obter ganhos de escala e, portanto, reduzir o custo de produção. O segundo motivo refere-se à carência de trabalhadores qualificados e suficiente capacidade empresarial.

O terceiro fator limitador concerne à adoção de processos de aprendizagem localizados e menos profundos, isto é, as empresas brasileiras caminharam menos sobre a curva de aprendizagem, ${ }^{17}$ restringindo a redução dinâmica de custos. Tal fato está relacionado aos outros dois fatores aludidos, no sentido de que estes constituíram-se em fontes impeditivas de obtenção de economias de escala (do ponto de vista estático) que elevariam o nível de produção e, como a curva de aprendizagem depende do nível de produção, provocaria um efeito no sentido de limitar a redução de custos.

Um quarto fator reside no fato de que, em mercados em que há cerrada proteção, a dinâmica tecnológica direciona-se para adaptação e melhoria de produto em detrimento da busca de inovações de processo com o objetivo de redução de custos (este tipo de inovação ocorre mais freqüentemente em paises mais abertos à competição). Excessiva proteção e falta de competição reduzem a necessidade dos produtores de melhorar sistematicamente a qualidade do produto e a busca de eficiência produtiva (introdução ou imitação de inovações de processo que elevem a produtividade dos insumos). Na literatura econômica, este fenômeno, que se manifesta microeconomicamente, é denominado de ineficiência $X$ e muitas vezes não the é reservado a devida importância. A ineficiência $X$ e rendas de monopólio, para o Brasil, foram estimadas no começo dos anos 70 , revelando que representavam $6,8 \%$ do $\mathrm{PIB}$, enquanto as ineficiências alocativas significavam apenas $0,3 \%$ do PIB (Barrionuevo, 1995, p.18).

Ao determinar uma estrutura industrial concentrada, o ambiente econômico brasileiro, caracterizado pelo mercado protegido e de dimensões reduzidas em virtude da lógica do $\mathrm{MSI}$, fez com que a lucratividade dependesse do impedimento da entrada de novos produtores no mercado e de abastecimento por meio de importações (limitação da contestabilidade). Esta situação levou a um abalo e desvirtuamento da capacidade empresarial. Para encetar uma trajetória baseada na lucratividade e na expansão das empresas, os produtores domésticos concentraram o foco sobre a montagem de lobbies para garantir a reserva de mercado, os incentivos de toda a ordem e criar obstáculos à entrada de novas firmas no mercado. As empresas que lograram êxito nesta tarefa obtiveram lucros e conseguiram expandir seus negócios. Os produtores domésticos começaram, assim, a adotar

\footnotetext{
17 Para uma abordagem microeconômica do conceito de curva de aprendizagem como fonte de mudança dinâmica de custos, ver Pindyck e Rubinfeld (1994).
} 
um comportamento rent-seeking, ou seja, a busca por renda econômica sem se incorrer em risco, estimulado pelos próprios condicionantes do ambiente.

\section{6 - O esgotamento do modelo de substituição de importações}

Os elementos que gestaram historicamente os condicionantes do ambiente econômico brasileiro determinaram a gestação de um ambiente econômico pouco indutor à inovação e à incorporação de progresso técnico por parte das empresas. Ou seja, o ambiente econômico emitiu fracos sinais para as empresas no sentido de engajarem-se em esforços permanentes de busca tecnológica. Em conseqüência, não teve o poder de interferência nas decisões microeconômicas sobre o comportamento tecnológico das firmas. O grau de lucratividade das empresas apresentava frágeis elos com a capacidade inovativa exibida pela empresa.

A conseqüência direta do seguimento desta trajetória foi o acumulo de hiatos tecnoiógicos e o distanciamento da fronteira mundial da tecnologia com a conseqüente perda de competitividade da estrutura industrial brasileira, sendo responsável pela estagnação da produtividade verificada nos anos oitenta. Além disso, verificou-se o acúmulo de ineficiências alocativas e o estímulo ao comportamento rentista (rent seeking). $\mathrm{O}$ aparato produtivo conseguia apenas produzir bens a um preço acima e com uma qualidade abaixo (medida em qualquer de suas dimensões) dos niveis internacionais. Este fato reforçou em diversos momentos a concepção de que a abertura da economia, com sua maior exposição à competição internacional, seria prejudicial ou lesiva à indústria nacional, dado o baixo nível de competitividade adquirido.

É detectado nos anos oitenta um agravamento deste quadro em virtude de profundas mudanças no cenário da economia mundial. A mudança do paradigma tecnológico ocorrida no final da década de setenta alterou significativamente a base técnica, gerando novos desafios e oportunidades econômicas. Para os Novos Países Industrializados (NPIs) que estavam preparados, o novo paradigma microeletrônico abriu "janelas de oportunidades" a serem exploradas (Perez \& Soete, 1988). Para os NPIs que não ostentavam as pré-condições necessárias (de modo geral, os países que adotaram o MSI como estratégia de desenvolvimento), o novo paradigma representou uma aprofundamento do abismo tecnológico, que levaria ao isolamento internacional.

\section{3 - MUDANÇA INSTITUCIONAL NO BRASIL DO INICIO DOS ANOS 90}

A Política Industrial e de Comércio Exterior (Pice) foi a política pública que promoveu a abertura econômica e representou uma tentativa de rom- 
pimento com a evolução histórica da industrialização brasileira, significando a busca da alteração de importantes condicionantes do ambiente que conformaram esta industrialização. A Pice pode ser interpretada como uma resposta ao esgotamento do Modelo de Substituição de Importações. A estratégia adotada foi a da inserção competitiva da economia brasileira no mundo. O principal instrumento para efetuar a abertura econômica foi a liberalização do comércio exterior.

A seguir, serão apresentadas a estrutura de comércio exterior antiga e a primeira tentativa de se efetuar uma liberalização comercial, embora de alcance limitado, através da Reforma Tarifária de 88 . Finalmente, será exposta a liberalização comercial promovida pela Pice.

\section{1 - Antecedentes}

A estrutura de proteção brasileira no final dos anos oitenta foi construída à luz da lógica do Modelo de Substituição de Importações (MSI) ao longo de sua vigência e apoiava-se, em certa medida, na Lei de Tarifas de 1957. Suas principais características eram as seguintes: a) tarifas altas e redundantes; b) abundância de regimes especiais; c) proliferação de controles quantitativos de importação; d) existência de tributos adicionais. Conforme destacado por Kume (1990), estes elementos caracterizadores estavam inter-relacionados e guardavam dependência entre si.

Este fenômeno (a proliferação de controles quantitativos) agravava-se com a constatação de que muitas destas barreiras não-tarifárias, mesmo que perdessem sua justificação estratégica ou funcional, permaneciam no ambiente econômico por inércia administrativo-burocrática ou por pressão de grupos de interessses organizados que se beneficiavam com a medida. A política comercial brasileira no final dos anos oitenta apresentava traços evidentes de irracionalidade, devido principalmente à redundância tarifária (Hahn, 1992), e discricionariedade em função da proliferação de controles quantitativos de importação (Fritsch \& Franco, 1991, p.14; Kume, 1990).

A primeira tentativa com o intuito de modificar a política de comércio exterior foi a Reforma Tarifária de 88 . Esta reforma teve um caráter limitado e pouco ambicioso por causa de sua natureza essencialmente tarifária. Ela conseguiu reduzir substancialmente a redundância tarifária, apesar de não tê-la eliminado. Houve uma redução generalizada das tarifas nominais em todos os gêneros e classes, à exceção da indústria extrativa mineral. Em conseqüência, a configuração das tarifas efetivas também se alterou. Pela observação da Tabela 1, percebe-se que 11 gêneros industriais exibiam tarifas efetivas abaixo das respectivas tarifas implícitas. Porém muitos gêneros continuavam com aliquotas acima da implícita. Isto se reflete no fato da 
aliquota média se situar aproximadamente $28 \%$ acima da tarifa média implicita, embora o desvio padrão das alíquotas de 88 seja inferior em aproximadamente $23 \%$, denotando uma maior uniformidade tarifária.

De prático, eliminaram-se alguns tributos adicionais como o lOF e a Taxa de Melhoramento de Portos (TMP). Porém o Adicional de Frete para a Renovação da Marinha Mercante (AFRMM) permaneceu em vigor. A Reforma de 88 também conseguiu eliminar alguns regimes especiais, embora mantivesse os mais importantes e significativos. Conforme estimativa de Kume (1990, p.126), os regimes especiais abolidos representaram somente $15,8 \%$ das importações totais, exclusive petróleo. Em compensação, deixaram incólumes os controles quantitativos às importações.

Enfim, a Reforma Tarifária de 88 assumiu um caráter parcialmente racionalizante, todavia foi incapaz de exibir uma natureza liberalizante. No aspecto de redução das tarifas efetivas, foi obtido relativo sucesso, dado que diminuiu o nível médio e modal da estrutura tarifária, assim como o seu grau de dispersão e variabilidade, engendrando uma maior uniformidade. $O$ êxito não foi completo, pois a redundância tarifária ${ }^{18}$ não foi eliminada. Em virtude da própria natureza limitante desta tentativa, a reforma não suprimiu, uma vez que não era seu objetivo principal, os regimes especiais e os controles quantitativos de importação.

\section{2 - A liberalização comercial de 90}

Tal iniciativa teve uma dupla natureza: racionalizante e liberalizante. Ademais, os objetivos eram de âmbito mais abrangentes, não se limitando a ser apenas uma reforma tarifária, e procurando romper os elos da estrutura passada. Assim, buscava-se suprimir o caráter discricionário e arbitrário da política de comércio exterior, que prejudicava a tomada de decisões das empresas, ao introduzir fortes elementos de incerteza e de risco nos seus horizontes de planejamento.

Tabela 1 - Tarifas efetivas por gênero da indústria

\begin{tabular}{l|r|r|r|r|r|r}
\hline \multicolumn{1}{c|}{ Gênero } & Implícita & \multicolumn{1}{c}{1988} & \multicolumn{1}{c|}{1991} & 1992 & \multicolumn{1}{c}{1993} & \multicolumn{1}{c}{1994} \\
\hline Agropecuária & $-15,30$ & 8,5 & 13,10 & 11,50 & 10,40 & 9,60 \\
Industria Extrativa Mineral & $-15,20$ & 10,3 & 1,38 & 0,28 & $-0,29$ & $-0,36$ \\
Minerais não-metálicos & 30,80 & 37,9 & 17,32 & 14,85 & 9,95 & 8,82 \\
Metalurgia & 44,80 & 43,7 & 27,41 & 23,35 & 19,82 & 16,89 \\
Mecânica & 14,00 & 50,7 & 34,71 & 29,65 & 24,09 & 23,06 \\
Material Elét. e de Comunic & 48,50 & 53,1 & 44,76 & 38,67 & 31,96 & 25,45 \\
Material de Transporte & $-9,80$ & 65,6 & 72,60 & 56,52 & 45,48 & 39,66 \\
Madeira & 35,20 & 31,3 & 10,80 & 10,50 & 10,20 & 10,00 \\
Mobiliário & 68,20 & 35,1 & 42,70 & 31,50 & 25,00 & 26,40 \\
Papel e Papelão & 42,20 & 34,2 & 104,59 & 104,54 & 104,57 & 104,61
\end{tabular}

\footnotetext{
${ }^{18}$ Redundância tarifária é dada pela diferença aritmética entre a tarifa legal média e a tarifa nominal implícita. Por sua vez, a tarifa nominal implicita é calculada pelo diferencial de preços internos e externos. (Hahn, 1992; Kume, 1990).
} 


\begin{tabular}{|c|c|c|c|c|c|c|}
\hline Borracha & 92,90 & 64,4 & 44,60 & 34,60 & 22,80 & 15,70 \\
\hline Couros e Peles & 23,70 & 38,6 & 13,30 & 11,90 & 10,20 & 8,40 \\
\hline Quimica & 42,40 & 22,2 & 11,35 & 10,00 & 8,58 & 8,22 \\
\hline Farmacêutica & 67,90 & 54,3 & 19,10 & 16,20 & 13,10 & 13,10 \\
\hline Perfumaria, Sabões e Velas & 81,30 & 114,9 & 64,80 & 40,90 & 33,90 & 26,10 \\
\hline Matérias Plásticas & 77,80 & 68,5 & 46,13 & 38,47 & 25,53 & 22,44 \\
\hline Têxtil & 125,60 & 72,7 & 47,40 & 35,21 & 29,23 & 19,21 \\
\hline Vestuário e Calçados & 164,40 & 102,3 & 55,89 & 44,87 & 32,00 & 23,76 \\
\hline Produtos Alimentares & $-1,30$ & 47,1 & 27,51 & 22,26 & 19,16 & 16,43 \\
\hline Bebidas & $-6,50$ & 90,1 & 108,00 & 89,30 & 51,50 & 24,80 \\
\hline Fumo & $-80,10$ & 93,2 & 133,30 & 117,60 & 98,70 & 54,70 \\
\hline Editorial e Gráfica & 1,90 & 14,9 & 10,80 & 9,20 & 8,80 & 8,40 \\
\hline Diversos & 84,20 & 78,9 & 43,20 & 35,10 & 27,10 & 20,40 \\
\hline Méd. & 45,15 & 57,80 & 46,68 & 38,82 & 31,03 & 24,60 \\
\hline Desvio padrão & 37,76 & 28,99 & 18,30 & 14,32 & 12,13 & 8,19 \\
\hline
\end{tabular}

Obs: Média ponderada pelo valor da produção

Fonte: elaborada e adaptada a partir de Kume (1990,p. 85) e Hahn (1992,p.39).

No que diz respeito ao aspecto tarifário propriamente dito, a liberaliz ação comercial de 90 propôs uma redução generalizada das alíquotas nom inais, que também modificaram a configuração das tarifas efetivas, conforme se pode apreciar pela Tabela 1. Na indústria de transformação, apenas o gênero Papel e Papelão apresentaria uma tarifa efetiva, em 94, superior à determinada pela Reforma de 88. A maior parte das aliquotas já seria infer ior no primeiro ano de vigência (1991) do que em 1988. A média simples da indústria de transformação declinaria de $57,80 \%$ para menos da metade ao longo deste periodo, ficando em $24,60 \%$ em 1994 .

Cabe frisar que a liberalização comercial de 90 preparou um cronograma gradual distribuído no tempo de redução e uniformização dos niveis tarifários (Tabela 2). O cronograma previa para 1994 uma tarifa menor que a metade daquela prevista para 1990, com desvio padrão reduzindo-se aproximadamente em $60 \%$ no mesmo período, enquanto a tarifa modal desde 1991 ficaria no nível de 20\%. A idéia era sinalizar irreversivelmente ao setor produtivo as tendências de liberalização e de uma maior integração competitiva da economia brasileira. A partir destes sinais, as empresas se $n$ tir-se-iam na compulsão de moldarem suas decisões estratégicas, levando em consideração em seus horizontes de planejamento estes novos rumos da política de comércio exterior do país.

Tabela 2 - Cronograma da reforma tarifária - 1991/1994 (em \%)

\begin{tabular}{c|ccc}
\hline Anos & Tarifa Média & Tarifa Modal & Desvio Padrão \\
\hline 1990 & 32,2 & 40,0 & 19,6 \\
1991 & 25,3 & 20,0 & 17,4 \\
1992 & 21,2 & 20,0 & 14,2 \\
1993 & 17,1 & 20,0 & 10,7 \\
1994 & 14,2 & 20,0 & 7,9 \\
\hline
\end{tabular}

Fonte: Erber \& Vermulm (1993, p. 43) 
As tarifas médias de importação efetivamente praticadas nos últimos anos são exibidas no gráfico 1 . Nota-se claramente que o cronograma previsto foi cumprido praticamente à risca, sem substanciais contramarchas.

Este fato foi importante para solidificar as expectativas do setor produtivo sobre a irreversibilidade da abertura econômica e da integração competitiva do país ao mundo. Assim, a abertura econômica foi implementada a despeito de descontentamentos setoriais e localizados, motivados pela frustração de interesses, muitos deles ligados ao comportamento rent-seeking.

Quanto aos regimes especiais de importação, segundo Hahn (1992, p.36), houve drástica redução destes mecanismos de isenção parcial ou integral da cobrança do imposto de importação, como o fim do programa Befiex. ${ }^{19}$

Gráfico 1 - Evolução Efetiva da Tarifa Média de Importação no Brasil (1988-96)

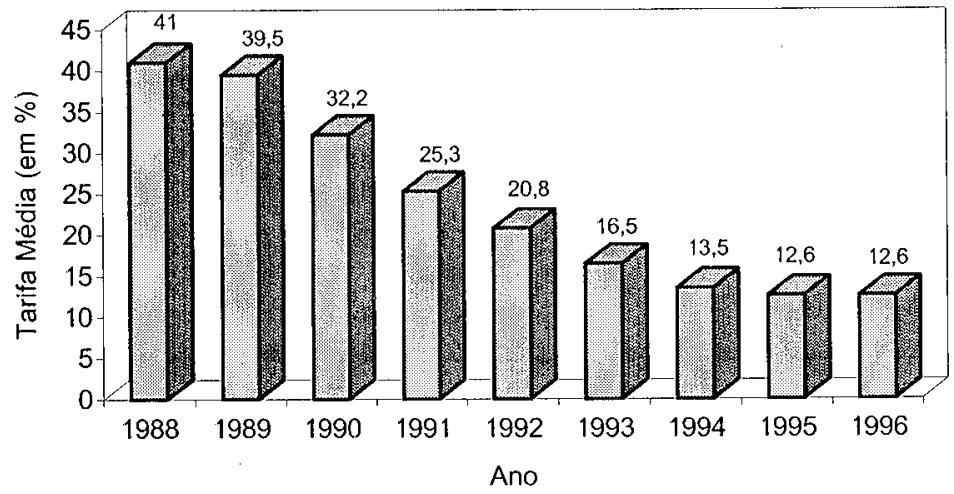

Fonte: Ministério da Indústria, do Comércio e do Turismo.

Eliminaram-se os controles quantitativos às importações, consubstanciados pelas restrições administrativas da Cacex, entre elas o conhecido Anexo C, que listava aproximadamente 1200 produtos (sobretudo bens de consumo) proibidos de ser importados, além da supressão do controle feito por guias de importações e da desobrigação das empresas de elaborarem programas de importação. Ademais, revogou-se a exigência de financiamento externo para importações de bens de capital e de grande valor e "uma modesta redução na exigência de conteúdo nacional praticada nos financiamentos subsidiados para a aquisição de bens de capital de produção local oferecidos pelo BNDES" (Fritsch \& Franco, 1992, p.50). Reduzi-

${ }^{19}$ Foram mantidos, no entanto, contratos Befiex já existentes, reduções tarifárias bilaterais ou multilaterais no âmbito do GATT e da Aladi, além da Suframa. (Hahn, 1992). 
ram-se drasticamente ainda "os bens de informática" proibidos de importação, para uma lista de 47 produtos, que, com a revisão da Lei de Informática em 1992, foi definitivamente extinta.

Logo, a liberalização comercial de 90 teve a capacidade de romper os elos da estrutura antiga que retirava diversas fontes de contestabilidade e de competição efetiva do ambiente e propelia os produtores domésticos a adotar um comportamento rent seeking. Ao reduzir substancialmente as alíquotas tanto nominais quanto efetivas para a indústria brasileira, influindo na matriz de ganhos (margens de lucro, valorização de ativos, market share etc) percebidos pelos agentes econômicos, eliminou o espaço para a emergência de tal comportamento.

Em suma, esta segunda tentativa, além de ter tido um caráter racionalizante, apresentou um fator liberalizante no ambiente econômico, sinalizando aos agentes econômicos uma grande mudança - profunda e irreversível da estrutura de proteção à indústria brasileira. Seu papel ultrapassou os limites de uma mera interferência no regime de comércio exterior e pôs em movimento expectativas com relação a um novo momento da economia. Além disso, constituiu-se em fator mutagênico fundamental na profunda modificação dos condicionantes do ambiente econômico brasileiro.

\section{3 - Interpretando a Pice e a grande mudança institucional}

Como já foi visto na seção 2 deste artigo, a conformação histórica dos condicionantes do ambiente econômico brasileiro, e sua influência sobre a dinâmica tecnológica, implicaram a acumulação de hiatos tecnológicos, provocando a discrepância do nível de produtividade e de qualidade da produção industrial doméstica dos parâmetros internacionais.

É nesse contexto que deve ser avaliada a importância do anúncio e da implementação da Política Industrial e de Comércio Exterior, na qual a Liberalização Comercial de 90 foi peça fundamental. Paradoxalmente, a relevância da Pice não deve ser julgada pela sua condição de política industrial. A maioria das medidas e instrumentos que garantiriam a implementação prática dos objetivos da Pice não foi levada a efeito, em decorrência da descontinuidade política e administrativa por que passou o governo que a criou ou da falta de recursos devido à crise fiscal. Porém, em essência, o objetivo e conteúdo da Pice estavam corretos ao procurarem influir nos principais condicionantes do ambiente econômico.

A importância da Pice residiu na liberalização do comércio exterior e a desregulamentação da economia, ou seja, na abertura econômica dentro da lógica do programa de fazer a integração competitiva da economia brasileira ao mundo. Este elemento da Pice - a abertura econômica - representou um ponto de inflexão na trajetória de desenvolvimento do país, ao mudar profundamente as regras do jogo econômico. Isto constitui o que é chamado 
neste trabalho como a grande mudança institucional - cuja característica assumida foi a passagem de uma economia fechada, ou semifechada, para uma economia aberta.

A conseqüência dessa mudança institucional radical foi a alteração profunda nos condicionantes fundamentais do ambiente econômico, induzindo a uma grande reorganização dos mercados, que provocou a mudança da mentalidade e da estratégia das empresas, induzindo-as à preocupação com a aquisição de capacitação tecnológica e busca de eficiência produtiva. Assim, a capacitação tecnológica das empresas foi induzida pela mudança do ambiente econômico que, por seu turno, foi provocada pela mudança institucional promovida pela abertura econômica, expressa, mais especificamente, pela liberalização comercial e, de modo geral, pela Pice (política pública).

Pode-se definir um primeiro periodo que compreende o ano de 1990 até 1992, em que o estímulo básico e predominante para a mudança foi a adversidade. As principais causas responsáveis na criação de um ambiente adverso foram o acirramento da concorrência tanto efetiva quanto potencial (contestabilidade por meio de entrada de novas empresas ou através da ameaça de importações), provocado pela abertura econômica e a eclosão da recessão ocasionada pela política de estabilização macroeconômica. As empresas responderam com programas de racionalização de custos e busca incessante de eficiência, com o intuito básico de defender seus mercados. O reflexo deste processo foi a redução concomitante do nível de produção e emprego, com a finalidade de permanecerem operantes no mercado. É a luta pela sobrevivência econômica diante dos rigores do ambiente,

Gráfico 2 - Evolução das Fusões e Aquisições no Brasil 1992-1998

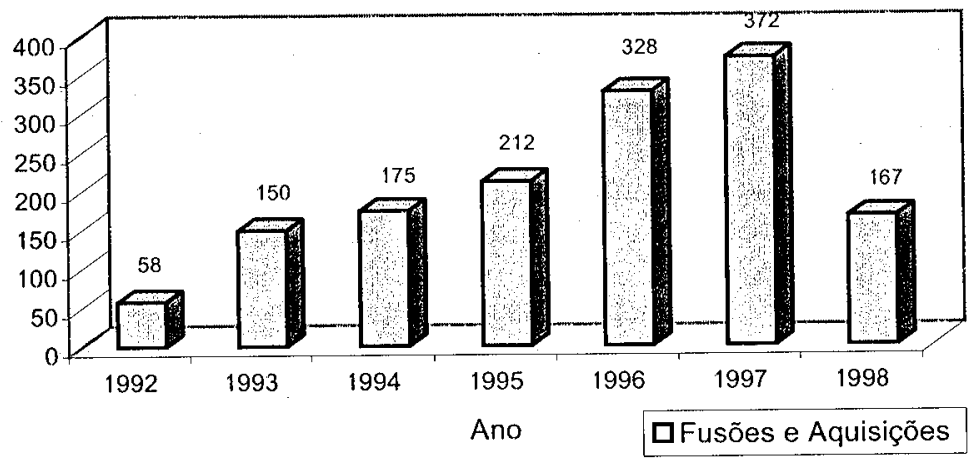

em que muitas não conseguiram se adaptar, desaparecendo. 
Nota: dados até junho de 1998.

Fonte: Consultoria e auditoria KPGM.

Uma segunda fase teve início principalmente a partir de 1993 na qual o estímulo predominante foi a exploração de oportunidades econômicas abertas pelo aprofundamento da difusão do paradigma microeletrônico no ambiente pós-abertura. Portanto as empresas que foram capazes de difundir novas tecnologias e inovações organizacionais (Just in Time, TQC etc) cresceram e expandiram o nivel de produção e a produtividade. Para explorar novas oportunidades econômicas, é necessário fazer investimentos produtivos e se preocupar mais intensamente com o processo inovativo (busca, imitação, aprendizado tecnológico, administração dos custos de inovação etc). A abertura econômica e o surgimento de oportunidades induziram a uma significativa reorganização dos mercados com a entrada de diversas empresas estrangeiras que eram mais capazes de fazer estes investimentos e difundir um novo padrão tecnológico e organizacional por meio de fusões e aquisições no mercado brasileiro. No gráfico 2, é mostrada a força assumida por este movimento patrimonial através da evolução de fusões e aquisições de empresas brasileiras por empresas estrangeiras. ${ }^{20}$

\section{4 - ALGUMAS EVIDÊNCIAS EMPÍRICAS}

\section{1 - Os dados}

Na apresentação das evidências empíricas será feito uso da série univariada de produtividade física média parcial do trabalho, no conceito de horas pagas na produção (HPP), da PIM-IBGE para Indústria Geral, contendo dados mensais, com início em janeiro de 1985 e término em dezembro de 1994, perfazendo, assim, 120 observações.

A fórmula para este indicador de produtividade é a seguinte:

$$
\rho=\frac{P F}{\operatorname{HPP}}
$$

na qual é a produtividade média do trabalho, PF é a produção física, HPP é o indicador de horas pagas na produção.

$O$ indicador de horas pagas na produção (HPP) capta horas não efetivamente trabalhadas como, por exemplo, férias, feriados, descanso remunerado, licença por enfermidade, maternidade etc. No que tange à questão da terceirização de atividades administrativas e de apoio, uma vez que este indicador refere-se a horas pagas na produção, ou seja, que dizem respeito

${ }^{20}$ Não estão consideradas nas estatísticas de aquisições as privatizações de empresas públicas ou estatais. 
direta ou indiretamente ao processo, o fenômeno desta terceirização não interfere, por definição, neste indicador, pois tais atividades nunca fizeram parte da sua base de dados.

A produção física da PIM-IBGE é um índice de quantum de Laspeyres baseado no acompanhamento das quantidades físicas de produção industrial por produto. A produção por produto recebe ponderações dadas pelo valor dos ramos industriais de cada produto, correspondentes a um ano base. As atuais ponderações foram obtidas do último censo industrial, realizado em 1985. O painel da PIM é composto por 8400 estabelecimentos (ou aproximadamente 5000 empresas) e 736 produtos. $^{21}$

\section{2 - O método}

Como a série de produtividade física média do trabalho sofre duas grandes intervenções no período de análise (eclosão do processo de abertura econômica e confisco dos ativos financeiros do Plano Collor), pretendese fazer uma análise de outliers, aplicando o Joint Estimation Procedure (JEP), método desenvolvido por Chen \& Liu (1993a e 1993b) no começo dos anos noventa.

O JEP é um método robusto de estimação conjunta dos parâmetros do modelo e de detecção de outliers. O método detecta quatro tipos de observações discrepantes: a) outlier aditivo (AO), cuja característica é causar um impacto imediato sobre o nível da série de tempo observada, afetando apenas uma única observação, localizada um ponto no tempo, voltando a série ao padrão normal na observação seguinte, ${ }^{22}$ b) outlier inovacional $(\mathrm{IO})$ que representa um choque aleatório (inovação) extraordinário em um certo momento, que, por sua vez, tem efeito dinâmico divergente ou convergente, propagando-se sobre as observações subseqüentes por meio da memória

\footnotetext{
${ }^{21}$ As principais críticas sobre a qualidade do indicador de produtividade disponível são de duas ordens. Em primeiro lugar, refere-se à desatualização cadastral do painel de empresas da PIM , uma vez que tal painel é baseado no censo industrial de 1985. Assim sendo, este cadastro seria incapaz de refletir as tendências e mudanças na distribuição da produção (desverticalização e a terceirização produtiva). Por conseqüência, isto levaria à superestimação da produção física e à subestimação do índice de trabalho (pessoal ocupado na produção ou horas pagas na produção), provocando elevações espúrias da produtividade. Outro grave problema é a desuniformidade cadastral no âmbito dos indicadores da PIM: o cadastro de empresas pesquisadas para a confecção dos indicadores de trabalho (HPP e POP) representa um subconjunto do painel de empresas pesquisadas na elaboração do indicador de produção física (PF). Ver mais a respeito em Villela e Silva (1994).

${ }^{2}$ Por exemplo, uma série mensal de produção de certa indústria pode ser afetada, em um mês, por uma greve de trabalhadores daquela indústria. Isto será refletido na série por um outlier aditivo (AO) no mês da greve com uma queda brusca da produção, voltando a série para seu padrão normal na observação seguinte (quando a greve já estará encerrada, e os trabalhadores já tenham voltado ao trabalho).
} 
do sistema descrito pelo modelo; c) outlier de mudança permanente (e de caráter abrupto) de nivel da série temporal - level shift - (LS); d) outlier de mudança temporária de nível - temporary change - (TC); deste modo, o outlier tem um efeito inicial num primeiro momento, porém de caráter temporário e convergente, pois decai exponencialmente a certa taxa com o transcorrer do tempo. Posteriormente, o método iterativamente ajusta as estimativas dos parâmetros do modelo, levando em consideração a influência dos outliers detectados. ${ }^{23}$

A idéia que está por trás é que os outliers detectados se comportam como sentinelas que emitem sinais de alerta sobre o que está ocorrendo de "estranho" a respeito da série, ou seja, todo fenômeno externo que impacta a série e que foge do padrão preditivo determinado pelos dados. Logo, não basta somente corrigir as estimativas dos efeitos dos outliers, mas também tentar investigar e interpretar as possiveis causas das observações discrepantes.

O Joint Estimation Procedure (JEP) tem basicamente três funções: a) obter melhores (mais precisas) estimativas dos parâmetros de um modelo; b) destacar algumas observações que necessitam ser submetidas a posterior investigação mais aprofundàda de suas causas; c) servir como instrumento para teste de hipóteses.

Neste sentido, percebe-se claramente que o JEP é um campo fértil para execução de testes de hipóteses. Especialmente, no que concerne à análise de intervenções e de tratamentos ou, como ficou convencionado na literatura estatística, à análise de séries de tempo interrompidas (interrupted time series analysis).

Considera-se o JEP apropriado para tal propósito em função de duas de suas propriedades: estimação melhor (menos viesada) dos parâmetros do modelo e a função de teste de hipóteses, principalmente a respeito de séries de tempo interrompidas. Para medir com precisão os efeitos de uma intervenção ou tratamento, faz-se mister possuir estimativas robustas e nãoviesadas dos parâmetros do modelo, as quais servirão de base de referência para a análise do impacto intervencionista.

O objetivo é usar a detecção de observações discrepantes para se avaliar os efeitos de duas grandes intervenções no ambiente econômico brasileiro no começo dos anos noventa: a abertura econômica e o confisco dos ativos financeiros do Plano Collor.

\section{3 - Expectativas quanto ao sinais, impactos e momentos do break}

${ }^{23}$ Para uma apresentação extensiva do método JEP, ver Chen \& Liu (1993a e 1993b), Liu \& Chen (1991) e Almeida (1996). 
O início do processo de abertura econômica dá-se em março de 1990, com o anúncio da Pice. Mesmo que as alíquotas de importação só começassem a se reduzir efetivamente em fins de 90 e no começo de 91 , havia já sido anunciada a política de liberalização comercial e redução tarifária pelo governo. Este anúncio ajudou a criar um clima de expectativas no ambiente empresarial, que começa a sentir os novos estímulos e pensar nas respostas apropriadas a fim de modificar sua conduta.

Espera-se, basicamente, que ocorram efeitos do processo de abertura econômica sobre a série de produtividade industrial do trabalho em três dimensões. Primeiro, um impacto positivo, ou seja, que a abertura tenha um efeito no sentido de elevar a série do indicador de produtividade. Este fenômeno manifestar-se-á no sinal do parâmetro que expressa o efeito do outlier. Logo, aguarda-se que o sinal deste parâmetro seja positivo.

Segundo, existe um efeito retardado (delay), ou seja, a adaptação a ambientes cambiantes de empresas heterogêneas, com respeito a sua nafureza, capacitações e assimetrias tecnológicas, demanda tempo. A conseqüência disto é a impossibilidade de saber com exatidão o momento do break estrutural, uma vez que a influência da abertura sobre a série manifesta-se com certo retardo devido ao fato de que a mudança de comportamento das empresas depende de sua capacidade de assimilação e de resposta, que naturalmente requer um determinado período de tempo para se efetivar. Espera-se que haja, em primeiro lugar, uma resposta defasada ao estímulo da adversidade (racionalização de custos); e posteriormente, uma resposta - mais intensa (portanto de maior impacto) - a oportunidades econômicas (difusão de novas tecnologias e inovações organizacionais) com uma defasagem temporal maior com relação ao anúncio da abertura, pois envolve a tomada de decisões de investimento e a sua implementação efetiva. Ademais, a incorporação plena de progresso tecnológico não é auto" mática e instantânea, mas cumulativa, dependente de trajetórias passadas e de processos de aprendizado, que precisam de tempo para maturar e apresentar frutos.

Terceiro, espera-se um impacto duradouro sobre a série, pois considera-se que a abertura foi uma mudança estrutural no ambiente econômico e, por conseguinte, uma mudança de nivel (representada por outlier LS) ou alteração de tendência da série (que pode ser representada por um IO).

Uma questão relevante, sempre a ser considerada em análises de séries de tempo interrompidas, é o momento do break estrutural. ${ }^{24}$ Para o caso da abertura econômica, não é razoável admitir o momento do anúncio como break point, dado que um natural efeito de retardo deve ser considerado

\footnotetext{
${ }^{24} \mathrm{O}$ modelo de intervenção de Box-Tiao (1975), por exemplo, exige uma especificação prévia do momento do ponto de ruptura provocado pelo tratamento.
} 
apos o anúncio da política de tratamento. E não se encontram elementos objetivos e sólidos para se arriscar um periodo. A adoção do Joint Estimation Procedure (JEP) dispensa o pesquisador desta tarefa ingrata. O primeiro outlier detectado que sinalize um efeito mais duradouro pode ser considerado como o momento do break.

Quase ao mesmo tempo houve uma outra intervenção de impacto sobre o ambiente econômico brasileiro - o seqüestro dos ativos financeiros do Plano Collor. É opinião corrente que tal intervenção de cunho macroeconômico teve um efeito persistente sobre a trajetória da produtividade, em virtude da grande contração de liquidez gerada. A especulação neste trabalho, ao contrário, é no sentido de considerar tal fenômeno como não tendo este caráter persistente sobre a série.

O Plano Collor foi uma intervenção de natureza conjuntural, realizada em março de 1990, com objetivo de se alcançar a estabilidade macroeconômica, mas que não teve sucesso. Na verdade, está-se mais diretamente interessado em descobrir o efeito de um elemento constituinte do plano de estabilização - o bloqueio dos ativos financeiros. Todavia é inegável que o pilar fundamental de sustentação do plano foi a iniciativa de se fazer o seqüestro.

As expectativas de como o efeito do seqüestro influenciou a variável produtividade são as seguintes: a) direção negativa, no sentido de reduzir o nivel de produtividade do trabalho; b) impacto imediato; c) efeito transitório.

Aguarda-se que a direção do seqüestro dos ativos financeiros sobre a evolução da produtividade tenha se manifestado em duas dimensões. Pelo lado da demanda, ao reduzir a demanda agregada da economia, diminuiu, em conseqüência, a produção física, sem a redução, na mesma proporção, do número de horas trabalhadas ou do pessoal ocupado. O fator de produção trabalho é mais rígido em seu ajuste devido a razões institucionais, principalmente no que concerne à legislação trabalhista. Assim, a produção física é mais sensível a movimentos conjunturais da demanda agregada da economia. O resultado final disto, pelo lado da demanda, é a redução do indicador de produtividade do trabalho.

Pelo lado da oferta, o bloqueio dos ativos financeiros das empresas representou uma asfixia com conseqüente estrangulamento do processo de produção, pois as firmas ficaram sem recursos para adquirir matériasprimas e insumos básicos necessários para a continuidade da produção. Este fato deve ter sido responsável por parte da redução da produção no curto prazo.

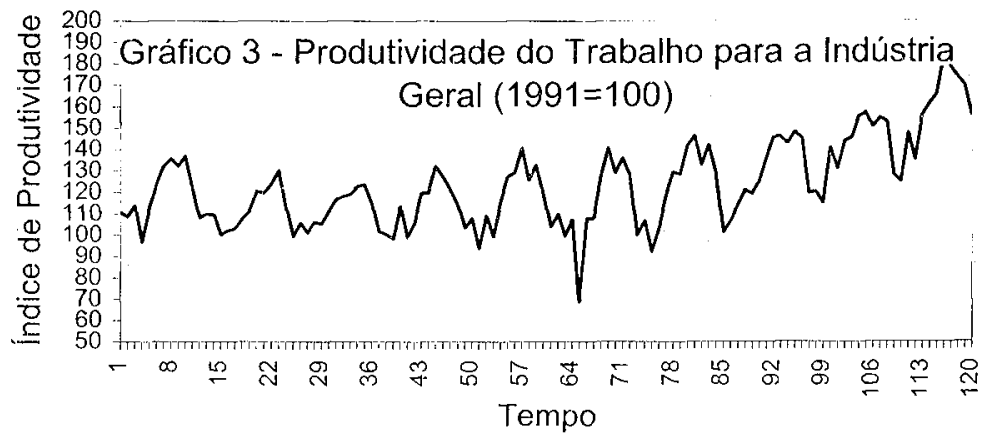


Fonte: Pesquisa Industrial Mensal (PIM-IBGE).

É esperado, portanto, que a ação conjugada destas duas forças implicasse uma diminuição do nivel de produtividade do trabalho, medido como uma relação entre a produção física e um indice de quantum de trabalho (horas pagas ou pessoal ocupado).

\section{4 - Resultados para a indústria geral ${ }^{25}$}

A evolução temporal do indice mensal de produtividade média do trabalho para a indústria geral é mostrada no Gráfico 3. Analisando esse gráfi$\mathrm{co}$, nota-se que há um marcante padrão sazonal na série.

Realizando o ajustamento sazonal dos dados pelo método Census $X$ 11 multiplicativo (Gráfico 4), e observando as Funções de Autocorrelação Simples (ACF) e Parcial (PACF) referentes à série ajustada sazonalmente de produtividade do trabalho para a indústria geral, conforme procedimento sugerido pela metodologia Box-Jenkins (1976), optou-se por ajustar o seguinte modelo ARIMA como satisfatório para representar o processo estocástico gerador da série:

$$
\nabla G_{t}=\left(1-\theta_{1} B\right) \text { at }
$$

no qual $G_{t}$ é o índice de produtividade física média do trabalho para a indústria geral; $\nabla$ é operador de diferenciação regular, 1 é o termo de média móvel de primeira ordem, $B$ é o operador de defasagem e $a_{t}$ é o termo de erro.

$$
\begin{gathered}
\text { Gráfico } 4 \text { - Produtividade do Trabalho para a Indústria Geral } \\
\text { com Ajustamento Sazonal }(1991=100)
\end{gathered}
$$

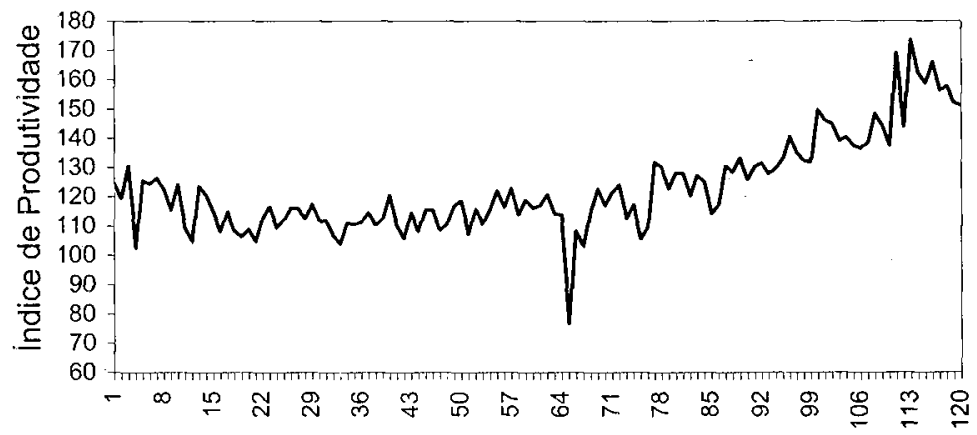

Tempo

${ }^{25}$ Para se obter o produto da estimação, foi usado o pacote estatístico SCA Statistical System, no qual está implementado o método JEP. Para maiores informações sobre este pacote estatístico, ver Liu \& Hudak (1992) ou o site www.scausa.com. 
Fonte: Pesquisa Industrial Mensal (PIM-IBGE).

O modelo é estimado por meio do método de máxima verossimilhança. As estimativas dos parâmetros são apresentadas na segunda coluna da tabela abaixo:

Tabela 3 - Estimativas de parâmetros de modelo e efeitos de outliers para a produtividade do trabalho da Indústria Geral, usando o modelo ARIMA (2)

\begin{tabular}{|c|c|c|c|c|c|}
\hline Parâmetros & Estimativas & \multicolumn{4}{|c|}{ Estimativas } \\
\hline & Sem ajustamento de outlier & \multicolumn{4}{|c|}{ Com ajustamento de outlier } \\
\hline 1 & $0,662(9,61)$ & \multicolumn{4}{|c|}{$0,701(10,12)$} \\
\hline $\mathbf{a}$ & 8,066 & \multicolumn{4}{|c|}{5,892} \\
\hline$Q(12)$ & 8,5 & \multicolumn{4}{|c|}{7,1} \\
\hline$Q(24)$ & 13,8 & & & 1,3 & \\
\hline & & Tempo & Tipo & Estimativa & $t$ \\
\hline Outliers & & & $\mathrm{AO}$ & $-37,314$ & $-6,87$ \\
\hline Detectados & & & LS & 15,473 & 3,68 \\
\hline & & 100 & $\mathrm{TC}$ & 15,523 & 3,05 \\
\hline & & 111 & LS & 26,054 & 5,93 \\
\hline & & 112 & $\mathrm{AO}$ & $-21,612$ & $-3,83$ \\
\hline
\end{tabular}

Obs.: as estatísticas t estão entre parênteses.

O parâmetro do termo de média móvel ${ }_{1}$ mostra-se significante no nível de $1 \%$. O valor do parâmetro garante, preliminarmente, ao modelo a desejável propriedade da invertibilidade. Os testes rotineiros de verificação da excelência do modelo também não invalidam a adequabilidade dos resultados. Tanto a visualização gráfica dos resíduos estimados quanto as estatísticas $Q$ de Ljung-Box fornecem fortes indícios de que aqueles se comportam como ruído branco.

Ao se aplicar o Joint Estimation Procedure obtém-se a detecção dos outliers e, conjuntamente, as estimativas de máxima verossimilhança dos parâmetros, já ajustadas para os efeitos dos outliers detectados. Isto é apresentado na terceira coluna da tabela 3. A detecção foi feita com um valor crítico de $2,8 .{ }^{26}$ Adotou-se - que é o parâmetro que mede o efeito de amortecimento dinâmico do impacto do outlier - de valor igual a 0,7 para se identificar um outlier do tipo TC. ${ }^{27}$

No tocante à estimativa do parâmetro do modelo, o nivel de significância para o termo de média móvel de primeira ordem ${ }_{1}$ eleva-se, em virtude

\footnotetext{
${ }^{26}$ Adotando recomendação de Liu \& Chen (1991, p. 20), optou-se por escolher este valor crítico, uma vez que se tem uma série de tempo relativamente curta ( 120 observações).

${ }^{27}$ Um valor baixo para este parâmetro denota que a mudança provocada por este tipo de outlier esvanece mais rapidamente. Um valor alto para significa os efeitos do outlier, a despeito de serem temporários, demandam mais tempo para desaparecerem.
} 
do valor do parâmetro ter se elevado ligeiramente, após o ajustamento de outliers.

Com respeito ao $\hat{\sigma}_{a}$, percebe-se que este sofreu uma redução de aproximadamente $27 \%$, quando o ajustamento de outliers é empregado. Uma das conseqüências da influência dos outliers é inflar $\hat{\sigma}_{a}$. Perante o ajustamento, há uma redução de $\hat{\sigma}_{a}$.

Quanto às estatísticas $Q$ de Ljung-Box, nota-se uma redução de $Q$ para o teste conjunto das 12 e 24 primeiras autocorrelações, reforçando, assim, a convicção de que os resíduos estimados são ruído branco e, portanto, testemunhando a favor da adequabilidade do modelo selecionado.

No que concerne aos outliers propriamente detectados, é possivel extrair-se várias conclusões de relevo. De acordo com a terceira coluna da tabela 3, o método identificou cinco observações discrepantes ao longo da série. O primeiro outlier foi um $A O$ de impacto negativo, altamente significante $(-6,87)$, detectado em $t=65$ (maio de 1990), e de grande magnitude ($37,314)$. Tal outlier está provavelmente relacionado à adoção do Plano Collor e, mais especificamente, à influência negativa do confisco dos ativos monetários sobre a atividade produtiva e sobre a produtividade do trabalho. Como se trata de um $\mathrm{AO}$, provoca um efeito instantâneo (one shock effect) sobre a série, que se manifesta somente na observação que lhe deu abrigo, não tendo efeito duradouro ou permanente sobre o índice de produtividade. Convém notar que o período em que foi detectado - maio de 1990 - corresponde ao terceiro mês depois do momento do anúncio do confisco. Assim, para a indústria geral, a produtividade não sofreu a influência imediatamente após o anúncio, porém observou-se um atraso de três periodos até que os efeitos do sequiestro se manifestassem.

O segundo outlier identificado é um LS em $\mathrm{t}=77$ (maio de 1991) de impacto positivo e de grande magnitude $(15,473)$. Um LS positivo é caracterizado por provocar uma mudança de nível para cima na série temporal, tendo a capacidade de exercer uma influência duradoura sobre ela. É provável que este LS seja a resposta à adversidade, que é um reflexo inicial do impacto do processo de abertura econômica sobre os dados de produtividade da indústria geral. Como esperado, apresenta um efeito retardado, necessário para que houvesse um período de ajuste por parte das empresas aos novos condicionantes ambientais no sentido de racionalizar custos e buscar eficiência, a fim de sobreviver no mercado.

A observação discrepante seguinte é um TC de impacto positivo em $t=100$ (abril de 1993), e de magnitude de 15,523. Como se trata de um TC positivo, provoca uma mudança temporária - de cunho aumentativo - sobre a série, que se extingue com o passar do tempo por intermédio da influência da taxa de amortecimento sobre o impacto inicial, não exibindo efeito duradouro ou permanente sobre o índice de produtividade. 
Na observação 111 (março de 1994), surge um outro LS positivo, altamente significante $(5,93)$ e de grande magnitude $(26,054)$, sinalizando mais uma mudança de nível permanente para cima na série. Novamente, tal efeito duradouro de elevação do patamar da série constitui em forte indício da resposta a oportunidades econômicas (difusão de novas tecnologias e inovações organizacionais) em decorrência do impacto retardado do processo de abertura econômica detonado em 1990 sobre a produtividade do trabalho. Todavia este impacto permanente sobre a série temporal requereu um período mais extenso do que a resposta à adversidade para se manifestar - aproximadamente quatro anos depois de iniciado o processo que deflagrou a grande mudança institucional, em função de envolver processos que, naturalmente, demandam mais tempo (tomada de decisão de investimento e a sua implementação, processo de aprendizado tecnológico etc).

Finalmente, o último outlier identificado foi um $A O$ negativo em $t=112$ (abril de 1994). Como se trata de um outlier aditivo, todo seu impacto negativo sobre a série se encerra na própria observação hospedeira, sem efeitos ressoantes a posteriori, pois a série temporal volta imediatamente ao seu padrão anterior logo na observação seguinte. Este AO pode estar relacionado a fenômenos mais conjunturais influindo momentaneamente sobre a trajetória da produtividade, contudo sem impacto duradouro, uma vez que seu efeito é anulado na observação seguinte.

É interessante notar que a série temporal da produtividade média do trabalho da indústria geral pode ser dividida em duas fases (ver Gráfico 4): a primeira, que se poderia chamar de calmaria, até março de 1990, na qual a série apresenta um padrão bem-definido, aparentemente estacionária; a segunda fase, que poderia denominar-se de turbulência e na qual se concentram todos as observações discrepantes detectadas (AO, LS, TC) a partir de abril de 1990 em diante, que mudam o padrão da série. $O$ anúncio e início efetivo do processo abertura é marco de separação destas duas fases distintas.

\section{5 - CONCLUSÕES}

A análise da evolução histórica dos condicionantes do ambiente econômico brasileiro demonstra que houve a constituição de um ambiente pouco indutor e pouco estimulante na busca de inovação e na incorporação de progresso tecnológico. Isto deveu-se basicamente ao baixo padrão de competição predominante nos mercados. Destarte, todas as fontes de competição foram eliminadas do ambiente devido à política de proteção de mercado. A contestabilidade das importações foi suprimida pela adoção da estratégia de substituição de importações. A concorrência efetiva foi elidida por causa do relativamente reduzido tamanho do mercado. 
O Modelo de Substituição de Importações (MSI) foi um dos grandes responsáveis pela constituição deste ambiente pouco indutor que significou um abalo na capacidade empresarial, em virtude das suas próprias características constituintes - a inexistência de objetivos de longo prazo (dinamicamente consistentes), a falta de cobrança de metas aos beneficiados pela concessão dos incentivos, a ausência de prazos explícitos de término da proteção, a não-seletividade da proteção e da concessão de benefícios e incentivos, o estímulo ao comportamento rent seeking por parte dos produtores nacionais etc.

A conseqüência foi a acumulação de hiatos tecnológicos e o distancia* mento da fronteira tecnológica mundial pelo país. Este é o cerne da crise e esgotamento do MSI. O anúncio da abertura econômica, promovida pela Politica Industrial e de Comércio Exterior (Pice), foi uma resposta ao esgotamento do MSI. A abertura econômica representou a mudança institucional radical que alteraria profundamente os condicionantes do ambiente brasileiro.

A parte quantitativa do artigo revela resultados interessantes em favor da hipótese de que ocorreu um choque de produtividade. Primeiro, para a Indústria Geral, o impacto do confisco dos ativos monetários do Plano Collor apareceu em maio de 1990 como um AO e, portanto, sem nenhum efeito duradouro sobre a série de produtividade do trabalho. Segundo, a abertura econômica manifestou-se através de um LS positivo em maio de 1991, representando uma mudança de nível para cima da série. Em março de 1994, surge um outro LS positivo, mais intenso, que deve ser interpretado como um reforço do efeito da abertura.

\section{BIBLIOGRAFIA}

ALMEIDA, E. S. Mudança institucional e estrutural na economia brasileira do início dos anos noventa: uma abordagem evolucionista. São Paulo: IPE/USP, 1996. Dissertação (Mestrado, mimeo).

AMADEO, E. J. Opening, stabilization and the development prospects for Brazil. Texto para discussão $n^{\circ} 367$, PUC-RJ, dez. 1996.

ARAÚJO JR., J. T. Concorrência, competitividade e política econômica. In: BAUMANN, R. (org.) . O Brasil e a economia global. Rio de Janeiro: Editora Campus, 1996.

BAER, W. A Industrialização e o desenvolvimento econômico do Brasil. Rio de Janeiro: Fundação Getúlio Vargas, 1966.

BARRIONUEVO FILHO, A. A abertura do comércio exterior no Brasil: a economia política da mudança de estratégia de desenvolvimento. São Paulo: IPE-USP, 1995 (Tese de Doutorado).

BARROS, J. R. \& GOLDENSTEIN, L Avaliação do processo de reestruturação industrial brasileiro. Revista de Economia Politica, v. 17, $\mathrm{n}^{\circ} 2$ (66), abr.-jun. 1997. 
BIATO, F. A. et al. A transferência de tecnologia no Brasil. Brasilia: IPEA/IPLAN, 1973.

BIELSCHOWSKY, R. \& STUMPO, G. Internacionalização da indústria brasileira: números e reflexões depois de alguns anos de abertura. In: BAUMANN, R. (org.). O Brasil e a economia global. Rio de Janeiro: Editora Campus, 1996.

BONELLI, R. Produtividade industrial nos anos 90: Controvérsias e quase-fatos. In: $A$ Economia Brasileira em Perspectiva, v. 2, IPEA, Rio de Janeiro, 1996.

BOX, G. E. P. \& JENKINS, G. M. Time series analysis. forecasting and control. San Francisco: Holden Day, 1976.

BOX, G. E. P. \& TIAO, G. C. Intervention analysis with application to economic and environmental problems. Journal of the American Statistical Association, v. $70, n^{\circ} 349$, p.70-79, mar. 1975.

CANDAL, A. et alli. A industrialização brasileira - diagnósticos e perspectivas". In: BARROS \& VERSIANI. Formação econômica do Brasil: A experiência da industrialização. São Paulo: Saraiva, 1977.

CHEN, C. \& LIU, L-M. Joint estimation of model parameters and outlier effects in time series. Journal of the American Statistical Association, v. 88, n. 421, p.284-297, jun. 1993a.

CHEN, C. \& LIU, L-M. Forecasting time series with outliers". Journal of Forecasting, v. 12, p.13-35, 1993b.

CONSIDERA, C. \& SILVA, A. B. A produtividade na indüstria brasileira. Sumário Executivo, Ap. DIPES, n. 1, 1993.

ERBER, F. E \& VERMUL.M, R. Ajuste estrutural e estratégias empresariais. Rio de Janeiro. IPEA, 1993.

FAJNZYLBER, F. Competitividad internacional: evolución y lecciones". Revista de la Cepal, n. 36, p.7-24, dez. 1988.

FEIJO, C. A \& CARVALHO, P. G. As causas do aumento da produtividade industrial nos anos recentes: réplica a Considera e Silva. Rio de Janeiro, mimeo, IPEA, 1994.

FLEURY, A. Quality and productivity in the competitive strategies of brazilian industrial enterprises. World Development, v. 23, n. 1, p.73-85, jan. 1995.

FRANCO, G. H. B. Os parnasianos alternativos. Folha de S. Paulo, 24/11/1996a.

FRANCO, G. H. B. The Real Plan. Texto para discussão n 354, PUC-RJ, abril $1996 \mathrm{~b}$.

FRITSCH, W. \& FRANCO, G. H. B. Politica comercial, de competição e de investimento estrangeiro. Revista Brasileira de Comércio Exterior, n. 33, p.46-59, dez. 1992.

FRITSCH, W. \& FRANCO, G. H. B. Trade policy issues in Brazil in the 1990's. Texto para discussão $n^{\circ} 268$, PUC-RJ, out 1991.

FURTADO, C. Formação econômica do Brasil. São Paulo: Companhia Editora Nacional, 1987.

HAHN, L. M. D. A reforma tarifária de 1990: proteção nominal, proteção efetiva e impactos fiscais. Revista Brasileira de Comércio Exterior, n. 30, p.35-41, mar. 1992.

HUDDLE, D. Os 'leilões de câmbio' e o alcance de múltiplos objetivos de politica econômica: uma avaliação do sistema brasileiro. Estudos Econômicos, v. 2, n. 4, p.35-72, ago. 1972.

KUME, H. A política de importação recente e a reforma tarifária. São Paulo: IPE-USP, 1990 (Tese de Doutorado).

LIU, L-M. \& CHEN, C. Recent developments of time deries analysis in environmental impacts studies. Working Papers Series, n. 123, Scientific Computing Associates, P. O. Box 4692, Oak Brook, Illinois, ago. 1991.

LIU, L-M. \& HUDAK, G. B. Forecasting and time series analysis using the SCA statistical system. Scientific Computing Associates Corp. P. O. Box 4692, Oak Brook, Illinois, 1992. 
MERHAV, M. Dependência tecnológica: Monopólio e crescimento. São Paulo: Editora Revista dos Tribunais, 1987.

MOREIRA, M. M. \& CORREA, P. G. Abertura comercial e indústria: O que se pode esperar e o que se vem obtendo. Revista de Economia Política, v. 17, n. 2 (66), abr-jun. 1997.

NELSON, R. R. National innovation systems - a comparative analysis. Oxford: Oxford University Press, 1993.

PASTORE, A. C. \& PINOTTI, M. C. Produtividade real: uma análise sobre o crescimento da produtividade industrial na década de 90. Revista Fiesp-Ciesp Notícias, jan. 1995.

PEREZ, C. \& SOETE, L. Catching up in technology entry barriers and windows of opportunity. In: DOSI et al. Technical change and economic theory. London: Pinter Publishers, 1988.

PINDYCK, R. S. \& RUBINFELD, D. L. Microeconomia. São Paulo: Makron Books, 1994.

SCHUMPETER, J. A. The theory of economic development: an inquiry into profits, capital, credit, interest and the business cycle. Cambridge: Harvard University Press, 1934.

SCHUMPETER, J. A. Business cycles: A theoretical, historical, and statistical Analysis of the capitalist process. New York: McGraw-Hill Book Company, Inc., (1 $1^{0}$ ed.), v. I, 1939.

SUZIGAN, W. Experiência histórica de politica industrial no Brasil. Revista de Economia Politica, v. 16, n 1, p.5-20, jan. 1996.

SUZIGAN, W. Indüstria brasileira: origem e desenvolvimento. São Paulo: Editora Brasiliense, 1986.

SUZIGAN, W (ed.). Induistria: Politica, instituições e desenvolvimento. Rio de Janeiro: IPEA/INPES, 1978.

SUZIGAN, W. Industrialização e política econômica: Uma interpretação em perspectiva histórica. Pesquisa e Planejamento Econômico, v. 5, n. 2, p.433-474, dez. 1975.

VILLELA, A \& SILVA, R. Ganhos de produtividade: Aspectos conceituais e implicações econômicas Revista do BNDES, v. 1, n. 2, p.77-98, 1994.

WILLIG, R. D. Contestable Markets. In: EATWELL, J. et al (org.). The New palgrave - a dictionary of economics. London: MacMillan Press Limited, 1987. 